\title{
Economic Security of Higher Education Institution as Viable Strategy for Sustainable Development
}

\author{
Irina Pervukhina ${ }^{1}$, Marina Vidrevich ${ }^{1, *}$, Csilla Marianna Szabó ${ }^{2}$ \\ ${ }^{1}$ Ural State University of Economics, Ekaterinburg, Russia \\ ${ }^{2}$ TEMPUS Public Foundation, Budapest, Hungary \\ "Corresponding author.Email:mbv@usue.ru
}

\begin{abstract}
The recognition of sustainable development as a key objective for higher education institutions around the world has been steadily increasing for the last two decades. The main objective of the present work is to analyze some international practices in Eastern-Central European countries in facing the challenges of sustainable development and economic security in the higher education sector. More specifically first the authors focus on the experience of HEIs in Hungary. Then they provide preliminary analysis of the factors affecting sustainability and economic security of a regional HEI using the case of Ural State University of Economics (Ekaterinburg, Russia). On the basis of the findings, the authors proposed some recommendations for mitigating the exiting and possible risks that may have a negative impact on sustainable development and economic security of the University.
\end{abstract}

Keywords: Sustainable development, Sustainable education, Higher education institutions, Sustainable university, Economic security, Hungary, Russia.

\section{INTRODUCTION}

Development as a complex process is the ability of a national economy to generate and sustain an annual growth of macroeconomic indicators. The global development and penetration of new technologies into all spheres of human activity in the XXI century have significantly changed the patterns of modern economy and industrial production. As a result, fundamentally new products, services, technological solutions as well as new jobs have emerged. The process of generating and disseminating knowledge is becoming the key factor in reproducing social wealth and developing human capital, both in terms of its qualitative and quantitative growth. The link between three dimensions - economic, social and environmental - presents the concept of sustainable development.

The recognition of sustainable development as a key objective for higher education institutions (HEIs) around the world has been steadily increasing for the last two decades [1, 2]. In a broader sense, sustainability "implies the survival, the security, and beyond these, the wellbeing of a whole system, whether this is seen at local level, such as community, or at global level" [3, p. 512]. Sustainability in education means that "the state should ensure a predictable and stable budget for the operation of institutions" [4, p. 109]. However, not only the state but also the institution should make efforts to harmonize the sources and the expenditures. HEIs in Eastern-Central European countries have faced multiple challenges for the last 25 years that are associated with the transition from a post-communist to a capitalist country, such as liberalization, the growing number of students, changes in the higher education system related to the Bologna Process, and the inclusion in the European higher education area [5].

Researchers have taken on the identification of suitable strategies for implementing sustainable development into the institutional framework of HEIs, including teaching and learning, research, teachers' professional training, community outreach, and collaboration with other universities $[6,7]$.

Dynamic changes in the social life and digitalization of the economy could not but make an enormous impact on national education sectors, particularly on higher education. The large-scale introduction of information and communication technologies (ICT) into the educational process enables universities to significantly expand the scope of the participants, disregard of their territorial location. This ensures the availability of cognitive resources and the efficiency of their translation. 
Education is transforming into a functional infrastructure of the global economy, which leads to the emergence of unified world educational standards.

Higher education is becoming one of the most important investment tools targeting sustainability of the society, as it produces a new type of consumer goods and services, i.e. knowledge and training. However, a dynamically changing environment and knowledge growth may catalyze the emergence of real and potential risks, as students are conceptualized as consumers. On the other hand, increased consumerism may have a positive effect, namely, greater student centeredness as students are treated as stakeholders in systems where HEIs have to compete for their business. This competition has the potential to improve student learning by urging faculty to focus more thoughtfully on quality teaching [8].

The main objective of the present work is to analyze some international practices in facing the challenges of sustainable development and economic security in the higher education sector. More specifically first we focus on the experience of HEIs in Hungary. Then we provide preliminary analysis of the factors affecting sustainability and economic security of HEI in Russia using the case of Ural State University of Economics (Ekaterinburg, Russia). The authors offer some recommendations for mitigating the exiting and possible risks that may have a negative impact on sustainable development and economic security of the University.

\section{METHODS}

The research was Internet based, and utilized a literature review to investigate the issue of sustainability of the higher education sector and economic security of HEIs in the international perspective. Thus, we have looked upon the problem from different perspectives: from more general (global) to country-specific (Hungary and Russia) and, finally, to local (USUE as a regional university).

A SWOT analysis was used to assess the USUE current position in terms of economic security. The SWOT analysis covered the following aspects: the university solvency and financial discipline; the relevance of the existing infrastructure; teaching staff competence and flexibility of administration; and efficiency of business activities.

\section{RESULTS AND DISCUSSION}

\subsection{Economic security of higher education}

According to Barton and Dlouhá [5], there were three phases in the transition of higher education. The first period took place from 1990-1993, and its most important idea was the liberalization process in the governance structures, which focused on decentralizing management and administration, recognizing students' rights, and building more autonomous operations. Parallel with it, the number of students increased and their interest in humanities expanded. Moreover, the mission of HEIs also changed: besides teaching, the academic staff started to focus on research as well.

The second phase (1994-1999) introduced changes towards the systematic transition, such as struggling with the increased number of students, the lack of necessary financial resources, the appearance of private higher education providers, and the significance of quality assurance policy, i.e. the demand for well-defined and high academic performance of both professors and students. The Bologna Process was implemented in Central-Eastern European HEIs, and the priorities of the institutes began to converge with those of Western European. The third phase, from 1999 to 2014, brought in changes in higher education policies in terms of degree structure and quality assurance.

As universities play crucial role in knowledge society, they are believed to be "the key actors in achieving the sustainable future" [5, p. 48.]. In this role, they should interact with non-academic social actors, such as industrial and economic enterprises. In spite of all measures that have been introduced in Central-Eastern HEIs for the last few decades, the universities of these countries obviously lag behind the development level of Western European countries. Central-Eastern countries considerably underspend on higher education compared to the OECD average - both as a percentage of GDP, and as annual expenditure per student. Moreover, these countries underspend on R\&D in higher education and produce a fewer number of higher education graduates [5].

However, since 1990s, the original state-funding system has been changed and a tuition fee was introduced. Students who reached lower results at the secondary level school-leaving or higher education entrance exams should pay tuition fee if they wanted to start their university studies. Moreover, private HEIs, which emerged in the market in the early 1990s, generally had and have now very few state-financed places for students, thus, these students also must pay tuition fee. What is more, universities should interact with other stakeholders, especially companies and enterprises, providing them with research. Cooperation with other actors of society has several benefits for HEIs. First, both professors and students are involved in and can study and research real-life problems of industrial and economic companies. Second, HEIs could better prepare their students for the challenges of the labour market. Third, professors could gain some extra money when providing academic research for economic stakeholders. All these changes have had a significant 
impact - both positive and negative ones - on the economic sustainability of higher education.

Economic security of the higher education sector is understood as a process aimed at creating conditions for continuous adaptation of the economic mechanism of HEI to achieve goals in a changing environment. Thus, the security of the education system is characterized as a set of economic relations that counter the threat of imbalance and instability $[7,9,10]$.

Economic security of HEI is the functioning of the university within the framework of the current legislation, ensuring its economic independence, integrity and anti-crisis sustainable development as a social and economic enterprise, as well as response to external and internal threats [11].

The concept of university economic security is built on the basis of forecasting and assessing threats in terms of a degree of impact, time of occurrence, and potential damage. It also implies the process of combating threats and measuring costs incurred. The model that may help to ensure economic security should provide mobilization and efficient management of the HEI resources in order to counter possible external and internal threats that may jeopardize university sustainable development and selfpreservation [12].

Potential threats to the university economic security should be considered and analyzed within the framework of two main categories. The first category includes threats related to changes in economic, political, legal, social, international and other factors affecting the HEI performance. To deal with the threats of this category, it is essential to monitor quantitative and qualitative changes in the outside environment and plan upcoming changes in the university management system. The second category is composed of the threats related to sustainable development of the university as an economic and social system, which enables the university to gain its competitive advantage. The transition of the university management to a qualitatively new level can affect the factors of and threats to HEI economic security.

To sum up, a higher degree of economic security is directly linked to the presence of effective tools that ensure HEI sustainable development as a way to attain goals and objectives set. The choice of methods and techniques for enhancing university economic security is affected by specific features of education economics. The nature and areas of application of the model of HEI economic security are determined by external socialeconomic and institutional conditions.

\subsection{International Practice: Hungary}

According to the EU 2020 Agenda the target for higher graduation rates was set at an ambitious $40 \%$ in the age group of 30-34 years old [13]. Some countries had already overcome this ratio before 2020, while some others, among them is Hungary, have not reached the desirable rate [4]. For the last 2-3 years, a specific process has been going in Hungary in the higher education sector. The government decided to change the financial basis as well as the employers of universities. Till 2018, except for the very few private (foundational) and ecclesiastical universities, nearly all HEIs were state-owned. These universities had significantly many state-financed places for students; however, professors' income was regulated by the state as well. The Hungarian government started to change the maintenance of higher education transforming most state-owned universities to foundation-employed ones. At present, the maintainer of the HEI is the advisory board of the foundation, while the employer of all university employees, including the academic staff and the employees of the services, is the chair of the board. The advisory board is comprised of both economic stakeholders as well as politicians. These universities have become not totally private: the advisory boards of the foundations were given valuable properties by the state, and many students do not (still) have to pay tuition fee.

The new model raises some question that could be answered in some years. Could Hungarian foundation universities increase their efficiency? Could they better prepare their students for the challenges of the labour market and knowledge society? In several years, will they reach a better place in European or world university ranking? And finally, will they become economically more sustainable due to the change in their maintainer?

\subsection{Russian Practice: USUE}

Ural State University of Economics (USUE) is located in Ekaterinburg (Russia) and has the status of a federal, publically funded university. USUE is one of the leading universities in the Urals Region. As of January 1, 2020 , it ranked second in terms of the number of enrolled students and revenue. The University ranks third among universities of economics in the Russian Federation in terms of the number of enrolled students and sixth in terms of revenue.

The degree of economic security of HEI can be measured by a set of the parameters that characterize its economic status, infrastructure, employees, and the effectiveness of the main business processes.

We embarked on a SWOT analysis to assess the USUE strengths and weaknesses (internally) and the opportunities and threats (externally) the University is currently facing. The following aspects were considered:

- solvency and financial discipline;
- the relevance of the existing
infrastructure;
- teaching staff competence and
flexibility of administration;




\section{- $\quad$ efficiency of business activities.}

The main item on the University budget is compensation of employees. A substantial proportion of the budget is allocated to construction, updating of university facilities and the purchase of equipment. The university conducts a weekly and monthly analysis of the cash flow in order to monitor compliance with financial discipline.

The university has well-equipped teaching facilities, research laboratories and the library. The teaching and learning process with the use of on-line technologies is organized via virtual learning environment (VLE) and the Institute of Distance Education.

The results of the SWOT analysis revealed that there were many examples of integrating sustainable activities in teaching, research and operational practice in USUE. The University's financial position and infrastructure ensure management's and academic staff's commitment to sustainability and implementation of short-, medium-, and long-term plans recorded in USUE Charter.

At the same time the findings suggest that there is a dangerous trend of a declining quality of educational services due to a shortage of experienced teaching staff. The proportion of members of faculty with academic degrees is decreasing as a result of a reduction in the number of defended dissertations, staff turnover and aging. The analysis also highlighted low involvement of the university in the sustainable development of the region. The efforts that USUE has made in contributing to regional research sustainability activities are not sufficient. Another factor that is essential if the university is to enhance its economic security is to focus on regional higher education partnerships and public-private partnerships.

The results of the SWOT analysis demonstrated consistency with the previous study of USUE economic security [14]. Dvoryadkina and Guseynly made an attempt to measure USUE economic security by applying a set of the so-called conservative and creative factors for a five-year period from 2016 to 2020. By conservative, or traditional, factors they understand "objects, processes or phenomena that have formed in the long-term retrospect and are traditional for the organization of higher education" $[14$, p. 2], e.g. computers, teaching staff, income from business activities. Unlike traditional factors, creative factors are of a short-term nature and are attributed to HEI new types of activities, e.g. publications indexed in Web of Science or Scopus, number of enrolled foreign students, university rating. The findings showed that USUE can be ranked as HEI of the second (Year 2018 and 2020) and third category of economic security (Year 2016, 2017, 2019). Its economic security was mostly affected by creative factors; however, the impact of conservative factors cannot be neglected.
The obtained findings call for putting forward some recommendations that might mitigate the threats to USUE economic security caused by the growth of competition in the regional market of educational services and possible reduction of state funding.

1) Developing the model ensuring university economic security. Taking into account the specifics of the University (the university of economics), the model should comprise, at a minimum, the following blocks: administrative, financial, technological, human resources, legal, information, as well as departments providing support for its functioning. Organizationally, the model can be implemented as a separate structural unit headed by a vice-rector for security. The unit will be in charge of USUE economic protection and will use all available resources (financial, technical, intellectual, information).

2) The USUE management should focus on solving the following priority objectives:

- further development of the university digital educational environment in order to promote innovative interactive educational technologies that are most effective for implementing the student-center approach. The student-center approach, or competence-based education, focuses on the ability of students to develop important knowledge, values, aptitudes, and attitudes necessary to address complex issues graduates will encounter in their future personal lives and professional careers [15]. Lambrechts et al. identified three main characteristics of teaching and learning methods for achieving sustainable development competences: interactive and participative methods (e, g, the Socratic method, group discussion, role play; action oriented methods (e.g., learning through internships; and research methods (e.g., bibliographic research, case studies).

- the transformation of the university into an educational 'platform', or assembly, with such components as university infrastructure, content aggregators, mass open online courses (MOOCs), electronic textbooks, learning management systems (LMS).

3) Strengthening the financial component of the University economic security by involvement in the innovative development of the region, which should become a catalyst for attracting funds from the regional budget and private investors. This type of social activity may encourage faculty and students to focus more on research, grant-writing and technology transfer. This will increase the demand for young and highly qualified graduates in the regional labor market; and develop the market of life-long learning services. Eventually this will win the university goodwill and enhance its attractiveness as a participant of the Private-Public Partnership with the largest industrial enterprises, organizations engaged in the service, education and R\&D sectors; regional and local authorities. 
4) Establishing a Center for Teacher's Professional Training (CTPT). Faculty are often well trained in their disciplines, but creating effective and stimulating learning environments is not always part of their education. Hence, the CTPT is to aim at improving the professional level of teaching staff on the basis of advanced teaching and learning practices and pedagogical psychology. The Center will focus on creating a comfortable learning environment for the professional development of faculty members, pedagogical training of post-graduate students, the introduction of educational and pedagogical strategies, the promotion of innovative teaching and learning techniques, which eventually may result in higher quality of education in the university.

The implementation of these recommendations may affect the USUE competitive advantage and enhance its economic security.

\section{CONCLUSION}

Since the main objective of the present work was to analyze some international practices in facing the challenges of sustainable development and economic security in the higher education sector, the authors made an attempt to study the concept of sustainable university using the experience of Hungary and the case of USUE.

Education is the basis for attaining the goals of sustainable development and makes a major contribution to a transformation of society. Sustainability is an essential aspect of a university's reputation and prestige locally, nationally and globally.

Despite the key role in social transformation, HEIs have to cope with some external (e.g., stakeholders' interest) and internal (e.g., curricula) challenges and barriers in order to demonstrate sustainability and economic security.

Four recommendations were made to reduce the treats to USUE economic security: (1) building the model that reinforces university economic security; (2) the solution of the priority objectives such as further development of the university digital educational environment and transformation of the university into an education 'platform'; (3) the involvement in the innovative development of the region, and (4) establishing a Center for Teacher's Professional Training (CTPT).

HEIs can significantly affect the development and competitive edge of a country or a region directly and indirectly, since university educational and research activities can only be effectively optimized when their results are utilized by the economy [16].

In this regard HEIs need to intensify the development of their third mission and improve the quality of education.

\section{REFERENCES}

[1] M. Barth. Implementing sustainability in higher education. Learning in an age of transformation. London, Routledge, 2015.

[2] G. Michelsen. Policy, politics and polity in higher education for sustainable development. In: M. Barth, G. Michelsen, I. Thomas, M. Rieckmann (Eds.), Routledge Handbook of Higher Education for Sustainable Development, London, Routledge, 2016, pp. 40-55.

[3] S. Sterling. Learning for resilience, or the resilient learner? Towards a necessary reconciliation in a paradigm of sustainable education, Environmental Education Research, 16 (2010) pp. 511-528. DOI: https://doi.org/10.1080/13504622.2010.505427.

[4] E. Darabos, D. Máté. Hungarian Higher Education - Sustainability. Empirical study, SEA - Practical Application of Science, 3(9) (2015) pp. 109-116.

[5] A. Barton, J. Dlouhá. Examining the Transition Toward Sustainability in Higher Education in Central Europe. In: J. Vávra, M. Lapka, E. Cudlínová (Eds.), Current Challenges of Central Europe: Society and Environment, Univerzita Karlova v Praze, Filozofická fakulta, 2014, pp. 43 67.

[6] D. Ferrer-Balas, H. Buckland, M. de Mingo. Explorations on the University's role in society for sustainable development through a systems transition approach. Case-study of the Technical University of Catalonia (UPC), J. Clean. Prod. 17 (12) (2009) pp. 1075-1085. DOI: https://doi.org/10.1016/j.jclepro.2008.11.006.

[7] R. Lozano, M. Y. Merrill, K. Sammalisto, K. Ceulemans, F. J. Lozano. Connecting Competences and Pedagogical Approaches for Sustainable Development in Higher Education: A Literature Review and Framework Proposal, Sustainability 9 (2017) $1889 . \quad$ DOI: https://doi.org/10.3390/su9101889.

[8] L. Harrison, L. Risler, The Role Consumerism Plays in Student Learning, Active Learning in Higher Education 16(1) (2015) pp. 67-76.

[9] A. Wysokinska-Senkus, K. Raczkowski, Economic Security in the Context of Sustainability, Rural Development 6(1) (2013) pp. 454-462.

[10] I. Tarasenko, J. Bondarchuk, A. Verhun, O. Tarasenko, Modernization of the Higher Education System in the Context of Increasing the Economic Security Level, International Journal of Management, 11(9) (2020) pp. 595-606. DOI: https://doi.org/10.34218/IJM.11.9.2020.055 
[11] V. N. Batova, Ensuring the economic security of budgetary institutions of higher professional education in the new financing conditions, Accounting in budgetary and non-profit organizations, 16(28) (2013) pp. 29-43.

[12] M. N. Volkova, D. S. Ivannikova, Functional areas of the enterprise's security service, Socio-economic sciences and humanitarian studies, 4 (2015) pp. 144-147.

[13] F. Roth, A. Thum-Thysen. The Key Role of Education in the Europe 2020 Strategy, SSRN Electronic Journal, 2010. DOI: https://doi.org/10.2139/ssrn.1706704

[14] E. Dvoryadkina, K. Guseynly, Economic security of the university in the context of the pandemic: influence of conservative and creative factors, E3S Web of Conferences 291 (2021) pp. 05037. DOI: https://doi.org/10.1051/e3sconf/202129105037

[15] W. Lambrechts, I. Mulà, K. Ceulemans, I. Molderez, V. Gaeremynck, The integration of competences for sustainable development in higher education: an analysis of bachelor programs in management, J. Clean. Prod. 48 (2013) pp. 65-73. DOI: https://doi.org/10.1016/j.jclepro.2011.12.034

[16] M. Lukovics, B. Zuti, Successful Universities towards the Improvement of Regional Competitiveness: 'Fourth Generation' Universities, SSRN Electronic Journal, 2017. DOI: http://dx.doi.org/10.2139/ssrn.3022717 